\title{
GCU
}

Glasgow Caledonian

University

University for the Common Good

\section{Evolving as necessity dictates: home and public health in the 19th and 20th Centuries}

Apple, Rima D.; Breathnach, Ciara; Bryder, Linda; Greenlees, Janet

Published in:

Nursing History Review

DOI:

$10.1891 / 1062-8061.26 .48$

Publication date:

2018

Document Version

Author accepted manuscript

Link to publication in ResearchOnline

Citation for published version (Harvard):

Apple, RD, Breathnach, C, Bryder, L \& Greenlees, J 2018, 'Evolving as necessity dictates: home and public health in the 19th and 20th Centuries', Nursing History Review, vol. 26, no. 1, pp. 48-54.

https://doi.org/10.1891/1062-8061.26.48

\section{General rights}

Copyright and moral rights for the publications made accessible in the public portal are retained by the authors and/or other copyright owners and it is a condition of accessing publications that users recognise and abide by the legal requirements associated with these rights.

Take down policy

If you believe that this document breaches copyright please view our takedown policy at https://edshare.gcu.ac.uk/id/eprint/5179 for details of how to contact us. 
"Evolving as Necessity Dictates: Home and Public Health in 19th and 20th Centuries"

\author{
Rima D. Apple \\ Ciara Breathnach \\ Linda Bryder \\ Janet Greenlees
}

This collection began as a conversation between Rima Apple and Janet Greenlees several years ago. We were both researching different forms of health care in the home. Though the time period and the location of our studies were very different--one in 19th-century Manchester and the other in 20th-century Scotland--we soon recognized that we were both investigating the same phenomenon, the pivotal role women played in bringing modern health care to underserved and unserved populations. Knowing that our findings were not unique to our times and places, we sought out other historians whose work might complement and even challenge our conclusions. Linda Bryder and Ciara Breathnach agreed to join us in studying this research question during the summer of 2015. Our collaboration resulted in a panel presented at the American Association for the History of Medicine in 2016. Conversations continued with a workshop, "Locating health care in the home: The experiences and innovation of nursing in the domestic sphere from the UK to New Zealand, 1860-1960" held at the 2016 Society for the Social History of Medicine and with extensive correspondence. Together we identified striking similarities and differences among and between public health nursing in the Anglo-world. Some of the similarities resulted from environmental conditions, as health reformers in different parts of the world faced similar conditions; others were the direct result of concerned women seeking 
to improve the lives of those they considered their less fortunate sisters. The differences were usually the consequence of the particular situations in which these women found themselves. Collectively our research draws a fascinating transnational picture of these women who entered into private homes to instruct patients on how to keep themselves and their families well.

Our discussions focused on the following four cases studies. Apple’s analysis centers on 19th-century Manchester health visitors--working-class women whose roles were designed by and paid for by concerned middle- and upper-class women. These women entered the homes of the poorest residents teaching the principles of cleanliness and the practices of white-washing. Their first-hand observations of conditions there led them to extend their ambit to nutrition, infant feeding, and child health. Bryder focuses on the Royal New Zealand Plunket Society (initially the Society for the Health and Women and Children) as early 20th-century national anxieties over child health sent Plunket nurses into private homes. These women like the health visitors, offered advice on modern child care, and became important to mothers by providing emotional as well as practical guidance. Greenlees and Breathnach return to the northern hemisphere with studies of the Queen Victoria’s Jubilee Institute for Nurses (QNI), similar institutions shaped uniquely by their political and cultural circumstances. Greenlees notes that in Scotland Queen's Nurses received extensive training that could prepare them for only some of the situations they faced in the rural villages. Breathnach identifies denominationalism, the links between healthcare and the Poor Law, the presence of established traditional practitioners and the associated class issues as the key challenges that Queen’s Nurses faced in Ireland.

The history of philanthropy, particularly of public health visiting and of nursing, presents scholars with several challenges, often related to the poor record keeping typical in the initial phases of an institution's evolution. We used a range of methodological approaches and sources 
to explore the development and legacy of our respective case studies. All rely on annual reports, newspapers, parliamentary papers, medical and nursing journals, and personal correspondence to evoke a sense of how each scheme was perceived in and by the communities they served. Additionally, Greenlees’ innovative oral histories with retired Scottish Queen’s nurses provide a rich seam of knowledge about how domiciliary schemes operated in poor parts of Scotland from 1950-2000.

In many aspects, these agencies were quite different in terms of class and in terms of financial support. The intended clients of health visitors and the Queen's Nurses were the working class and the poor; the Plunket nurses attended all who invited them into their homes. The Manchester health visitors were initially working-class community women, who received minimal training and were supported by the philanthropy of local middle- and upper-class charitable women. However, as Medical Officers of Health recognized the benefits of these public-health workers, they were slowly incorporated into the formal structure and governance of public health departments and the position of health visitor was professionalized as a specialization of nursing. This provided a relatively secure funding stream for the health visiting but the women who were employed as health visitors were much less likely to be working-class. Plunket nurses were professionals from the outset, employed by the New Zealand Plunket Society, which zealously protected its independence from government control but was not averse to receiving government support, supplementing its voluntary funding. The Queen’s Nurses in Scotland and in Ireland were also professional nurses from the outset of the programs, and their finances varied. Communities aiming to establish a nursing position in their area had to form a District Nursing Association (DNA), which in turn had to give and undertaking to provide suitable accommodation and payment for the nurse. Contributions had to be raised from the 
communities they served; philanthropy and, in some cases, government agency funding were central to maintaining the positions. This contingent funding placed the nurses in a somewhat precarious position, uncertain at any given time on how much support they could depend.

Each program served a specific clientele, depending on the tenets of its sponsor and local conditions. The Salford and Manchester Ladies Sanitary Association focused on those living in the poorest sections of the cities and clearly announced that their health visitors were to visit all, regardless of creed. They accommodated both Catholics and Protestants. And, though they did not serve Jewish households, they did facilitate the establishment of the Salford and Manchester Jewish Ladies Sanitary Society. The services of the Plunket nurses were available to all New Zealanders regardless of religion or class, though the government ran a separate infant health service for Maori. The Queen's Nurses also focused their attention on the poor in Scotland and Ireland. In Ireland their welcome was tempered by householders' suspicions of outsiders, particularly those of a different culture or religion, while in Scotland the Queen's Nurse represented an approachable, recognized community health-care provider.

Although these projects, on the surface, appear quite different; our analysis highlighted more their common, underlying principles and practices. We found three most significant. The first is the aristocracy and the importance of marital connections that supported many of these initiatives; the second is the inventiveness of the practitioners who often worked under dire circumstances; the third is the importance of the relationship that developed between practitioners and clients.

The Manchester and Salford Ladies’ Sanitary Society and the Queen’s Nurses in both Ireland and Scotland relied on input of women of standing within their local communities for their foundation; elsewhere, aristocratic women with wide connections took the lead. The latter 
began with Lady Hariot Dufferin, whose husband Queen Victoria had appointed as viceroy in India in 1884. Concerned with issues of maternal health, Lady Dufferin established the Dufferin Fund in 1885 to train female doctors and provide midwifery training in remote areas of India. Lady Dufferin’s daughter, Lady Victoria Plunket was involved in founding the Plunket Society during her husband William's tenure as Governor of New Zealand, 1904-1910. Other aristocratic wives spread the health visitor and public health nursing movements to other parts of the Angloworld in the late 19th and early 20th centuries. When Lady Ishbel Aberdeen's husband was appointed Governor General of Canada, she founded the Victorian Order of Nurses in 1897. In Ireland, Lady Rachel Dudley, whose husband was the Lord Lieutenant of Ireland from 1902 to 1905, succeeded in placing the QNI on a sure footing in the remote Western counties. The scheme lasted until 1974, when the Regional Health Boards absorbed its functions. Lord Dudley was Governor-general of Australia from 1908 to 1911 and the year after this arrival the Lady Dudley’s Bush Nursing Scheme was in operation. These schemes were underpinned by a common denominator: a network of socially-minded and politically-connected female aristocrats who had a reach that extended throughout the British empire. They drew on the experiences of their predecessors and have origins in the ethos of groups such as the Manchester and Salford Ladies' Sanitary Society. All were founded after groups of women saw a need and who strove to fill it. All continued after individual communities acknowledged the benefits of certain kinds of home health-care provision and struggled to sustain it in their area, but relying on organizational support from a central body.

Health visitors, Plunket nurses, and Queen's nurses all faced unexpected circumstances when they entered the home. They could not simply follow a set of rules established by an agency outside the homes they visited. Facing unanticipated situations shaped by living, social, 
and cultural conditions, they struggled with the tasks they were assigned and developed inventive solutions to the problems they faced. Manchester health visitors faced poverty and unsanitary conditions in which they needed to convince their clients of the need for feasibility of basic cleaning techniques. Plunket nurses went beyond their brief of health education to offer charitable help and medical assistance when needed. Public health nurses in the rural West of Ireland, and the islands in particular, also faced dire poverty and unsanitary housing. Malnourishment, undernourishment, and illness were inevitable consequences of the prevailing socio-economic conditions; in addition, district nurses encountered a populace unaccustomed to modern medicine. So too in Scotland the Queen’s Nurses faced grinding poverty. They provided practical, charitable help, while also educating patients and their families about both health and healthcare.

Most critically, the stories of these nurses disclose how the patient-nurse relationship shaped health-care delivery in the nineteenth and twentieth centuries, strengthening our understanding of the work of public health nurses, in the past and today. These nurses sought to work with their clients, not impose their ideas on them. Of course, they saw that their advice was "correct," but they knew that it was not always immediately apparent to their clients. In the West of Ireland, the nurses found that their job was as much indoctrination as it was care. But, once trust was established, the provision of health care in the home was a resounding success and, as Breathnach shows, outcomes of birthing in the domiciliary context improved dramatically. In Scotland, the nurses also found they needed to bring reluctant householders along. Taking time to get to know their patients and their families, the Scottish Queen’s nurse used these networks of trust in health education. Both patients and their families were invited to participate in “experiments” to judge whether traditional medicine or the Queen’s Method was 
more successful. An unintended outcome was that the nurses also learned some new treatment methods. Plunket nurses also admitted learning from their clients, the mothers.

We hope that our research and the papers that follow stimulate more comparative and cross-cultural studies to test our conclusions about similarities among public health nursing programs. Our case studies examine the Anglo-world. Do our findings hold true for other parts of the world? Do such public health nursing programs typically begin outside governmental agencies? Regarding the financial support and sponsorship of public health nursing programs, each of our case studies emerged from a group of concerned women who recognized problems in their communities. Each was challenged by governmental and legislative interventions that changed the nature and even the scope of their work, including the Plunket Society, which held out against government encroachment until the 1980s (beyond the scope of the study presented here). [As a counterfactual historical question: could the Manchester health visitors have developed into a Plunket-like society without the intervention of government controls?] Have many (most) independent public health nursing programs been absorbed into public health departments? Is this a necessary step in the evolution of public health nursing or does it shift the focus away from patient-practitioner relations and associated, established networks of trust? If it is, how can we maintain community involvement to insure that programs are responsive to local needs and conditions? These questions are not new in the historiography of public health nursing, but building on case studies such as these can provide new insights and potential avenues for future research in addressing these critical issues.

In the process of developing these papers and this section, we have created an informal, but productive and supportive research group. Our collaborative work has enriched the individual projects and expanded our understanding of the nature of public health nursing 
historically and cross-culturally. Such collective work does not replace the research of the individual scholar, but it helps create more vibrant and comprehensive publications that will enhance the historiography of nursing. 